Przegląd Badań Edukacyjnych Educational Studies Review

ISSN 1895-4308

nr 20 (1/2015), s. 193-202

Marcin Wlazło

Uniwersytet Szczeciński, e-mail: asmaw@univ.szczecin.pl

\title{
Przemoc wobec osób niepełnosprawnych jako przedmiot studiów interdyscyplinarnych
}

DOI: http://dx.doi.org/10.12775/PBE.2015.044

\section{Violence Against the Disabled as a Subject of Interdisciplinary Studies}

\begin{abstract}
Violence is both a subject of scientific analyses and statistical studies, and a subject willingly undertaken by the journalists and writers. On the one hand, we obtain figures and attempts at systematising the phenomenon, on the other, there are stories of real or fictional characters who experience domestic violence, mobbing or cyberbullying. The presence of violence in the media, computer games and everyday life is a challenge not only for the police, lawyers and social workers, but also for psychologists, sociologists, anthropologists and educators analysing violence as a phenomenon accompanying the humanity since its prehistory. Violence implies a potential or actual physical weakness of its victims (children, women, animals) and/or remaining in the minority relation to its perpetrators (ethnic, religious, political, sexual minorities). In this structure a special place is occupied by disabled people, whose physical weakness and meeting the criteria of a minority group most often exacerbate problems related to violence against this social group. An accurate description and explanation of these issues require an interdisciplinary approach to the analysis of the factors causing and sustaining violence against people with disabilities.
\end{abstract}

Key words: violence, people with disabilities, interdisciplinary studies 


\section{Wprowadzenie}

Przemoc należy do kluczowych problemów i wyzwań współczesności, w istotny sposób oddziałujących zarówno na losy pojedynczych osób, jak i całych grup społecznych. Od opisu brutalnego morderstwa rozpoczyna się książka Prawa mniejszości, autorstwa Jennifer Jackson Preece (2007), by w ten drastyczny sposób wprowadzić czytelników w tematykę relacji międzyludzkich opartych na nierówności, dyskryminacji i administracyjnie narzucanej homogenizacji. Opisane w tej pozycji morderstwo „było tematem tysięcy artykułów gazetowych i programów telewizyjnych, przedmiotem działań sądu cywilnego i publicznego śledztwa" (Preece, 2007, s. 15), a przyczyną tak dużego zainteresowania tą sprawą nie była ani szczególna brutalność zajścia, ani bezkarność sprawców, lecz fakt, iż czarnoskóry człowiek został bez najmniejszego powodu zakatowany przez kilku młodych, białych mężczyzn.

Tragiczna historia pojedynczego człowieka stała się punktem odniesienia niekończących się analiz, dotyczących społecznych, politycznych i prawnych podstaw funkcjonowania grup mniejszościowych. Przykłady przemocy stały się dla autorki pracy na temat praw mniejszości punktem wyjścia do sformułowania „problemu mniejszości” i następujących pytań: „Dlaczego różnorodność tak często uznawana jest za zagrożenie dla politycznej wspólnoty? Czy stabilność rzeczywiście wymaga homogeniczności lub czy można ją utrzymać, jeśli istnieją różne grupy mniejszościowe?” (Preece, 2007, s. 6). Choć autorka przywołanego tekstu pomija niepełnosprawność jako jeden z czynników wyodrębniających grupy mniejszościowe (obok religii, rasy, języka i etniczności), to należy podkreślić, że to właśnie o osobach niepełnosprawnych mówi się w kontekście najliczniejszej grupy mniejszościowej w „przeludnionym teatrze wielokulturowości” (Goodley, 2011, s. 2), a studia nad niepełnosprawnością (disability studies) poszukują merytorycznego i metodologicznego wsparcia w zainicjowanych w latach 60. ubiegłego wieku studiach feministycznych i rasowych (women and black studies) (Boggs, 1996).

Jeżeli do praw kobiet i mniejszości rasowych dołączymy jeszcze dzieci i dwudziestowieczną walkę o ich prawa, to uzyskamy w miarę kompletny zestaw motywów uruchamiających podobne działania na rzecz osób niepełnosprawnych. We wszystkich wymienionych przypadkach punktem wyjścia jest wielowiekowa, wpisana w dzieje właściwie wszystkich kultur, przemoc powodowana mniej lub bardziej radykalnymi poglądami filozoficznymi i politycznymi, przesądami, uprzedzeniami, tradycjami czy wierzeniami. Globalna natura niepełnosprawności, ujawniająca niezależność tego zjawiska od poziomu 
zamożności społeczeństw czy ich gotowości do respektowania praw człowieka i obywatela, sprawia, że sytuacja osoby niepełnosprawnej jest wypadkową stosunku danego społeczeństwa zarówno wobec grup mniejszościowych, jak i wobec ogólnie pojętej, ludzkiej słabości w jej jednostkowym, wyjątkowym i niepowtarzalnym wymiarze.

\section{Przemoc jako ograniczenie wolności i równości}

Łączenie przemocy z relacją większości wobec mniejszości zakłada nie tylko oczywistą dysproporcję ilościową obu grup, ale także dążenie do zdominowania mniej licznej społeczności przez wzory zachowań typowe dla grupy większościowej. W sytuacji przeciwnej, znane również z historii Polski rządy oligarchiczne opierały władzę mniejszości na dominacji militarnej, ekonomicznej i intelektualnej, ukazując inny kierunek i wymiar obecności przemocy w życiu społecznym. Współczesne demokracje, zakładające równość wszystkich swoich obywateli, nie są wolne od mniej lub bardziej intencjonalnych działań ograniczających swobodę polityczną, religijną, językową czy seksualną. Podłożem ujawniających się różnic i związanych z nimi wykluczeń i dyskryminacji mogą być takie czynniki, jak płeć, wiek, rasa, etniczność czy sprawność psychofizyczna. Wymienione czynniki stanowią zarówno oczywiste potwierdzenie biologiczno-kulturowej istoty ludzkiego bytu, jak i uzasadnienie potrzeby umieszczenia rozważań nad przemocą w kontekście indywidualnym (biologicznym) i społecznym (kulturowym).

Współczesna opozycja liberalizmu i neoliberalizmu opiera się na założeniu, że wolność i równość wykluczają się, stanowiąc tragiczny i utopijnym wymiar ludzkich dążeń do społeczeństwa idealnego. Poprzednie dwa stulecia jednoznacznie zweryfikowały pomysły społeczno-ekonomiczne oparte na wzajemnym wykluczeniu kapitału prywatnego i państwowego. W obu przypadkach, zwłaszcza w skrajnych wersjach kapitalizmu i komunizmu, człowiek z jego niepowtarzalnością i indywidualnymi potrzebami nie istnieje, a jego miejsce zajmuje zniewolony element systemu. Liberalizm jako koncept społeczno-polityczny zboczył natomiast w kierunku obojętności (nieingerencji) wobec człowieka traktowanego jako byt samowystarczalny. W zwięzłej monografii liberalizmu Paul Kelly pisze:

Najlepszym sposobem ujmowania liberalizmu jest uznanie go za społeczną i polityczną teorię wolności jako szeroko rozumianej nieingerencji. A jeśli tak, to mogłoby się wydawać, że wolność z konieczności wchodzi w konflikt z równością, co 
zmuszałoby do wyboru między dwoma niewspółmiernymi wartościami. Jedynie utylitaryści mogą sobie pozwolić na luksus przekładania pojęć wolności i równości na pewną wyższą od nich wartość, jaką stanowi ich zdaniem użyteczność, pozwalająca na wyważenie wymogów wolności i równości. Liberalni egalitaryści nie mogą sobie pozwolić na taki luksus, nie mogą jednak również stwierdzić, iż równość w dowolnych warunkach musi przeważyć nad wolnością. Liberałowie uznają wolność za podstawową wartość, nawet jeśli podporządkowują ją pewnej idei równej troski i szacunku (2007, s. 87).

Pedagogiczne ujęcie wolności i równości skonkretyzowane zostało na gruncie emancypacyjnej teorii edukacji, stając się jednym z podstawowych wymiarów refleksyjności i krytyczności we współczesnych naukach o wychowaniu (zob. Czerepaniak-Walczak, 2006). W tym kontekście pojawia się, wprowadzone przez Marię Czerepaniak-Walczak (2005), pojęcie pułapek izonomii, stanowiące niezbędne dookreślenie debaty na temat relacji wolność-równość. Uświadamiając sobie, jak ważnym źródłem przemocy jest brak porozumienia między zróżnicowanymi grupami społecznymi (najczęściej w kontekście dominacji ilościowej i fizycznej), warto przytoczyć opinię wymienionej autorki na temat inkluzji (wkluczania) i integracji społecznej:

Procesy wkluczania i integracji natrafiają na opory i przebiegają z trudnościami nie tylko ze względu na niechęć osadzoną w postawach ludzi, ich niewiedzy i stereotypach. Poważnym zagrożeniem są naiwne, sentymentalne nastawienia wyzwalające tendencje filantropijne, charytatywne. Są one specyficzne dla liberalnego oraz paternalistycznego modelu integracji. Generują one wiele zasadzek i pułapek zakłócających proces rzeczywistego integrowania się osób i grup o odmiennych właściwościach. Wśród nich na wyróżnienie zasługują te, które nazywam pułapkami izonomii. Są one przejawem i następstwem formalnego nadania prawa równego uczestniczenia, administracyjnego zadekretowania go. W te pułapki wpadają zarówno ci, którzy prawo to nadają jak i ci, którym jest ono nadawane (Czerepaniak-Walczak, 2005, s. 14).

Tego typu poglądy korespondują ze zmianami paradygmatycznymi na gruncie pedagogiki specjalnej (Krause, 2010), zmierzającymi w kierunku refleksyjnego i krytycznego (emancypacyjnego) współudziału osób niepełnosprawnych w procesie własnej edukacji i rehabilitacji jako podstaw autonomicznego udziału w życiu społecznym. Doskonale wiadomo, że wystarczyłoby przestrzegać obowiązującego prawa, by nie tylko osobom niepełnosprawnym 
zapewnione zostały elementarne podstawy bytu i bezpieczeństwa, a walka o prawa zastąpiona została korzystaniem z uprawnień. Jest to, niestety, kolejne wcielenie społecznych utopii, ignorujących fakt, że wolność i równość należy traktować jako wartości i prawa powszechne, ale jednocześnie wymagające odpowiedzi na proste pytanie: czy dany człowiek jest zdolny do korzystania $\mathrm{z}$ wolności i równości? Tak postawiony problem powinien nam od razu uświadomić, że jednolita istota przemocy (w jej historycznych i społecznych uwarunkowaniach i wymiarach) ulega istotnemu zróżnicowaniu, gdy rozważamy zaangażowanie kobiet, dzieci, Murzynów, gejów czy osób niepełnosprawnych w walkę o własne prawa.

Nie wchodząc w tym miejscu w bardziej rozbudowane i w sumie dość oczywiste dywagacje, chcę jednak wskazać, że problematyka przemocy i ogólnie - relacji społecznych grup narażonych na marginalizację, ma swoje polityczne uwarunkowania i konsekwencje, te z kolei skłaniają do pogłębionych studiów filozoficznych, historycznych, socjologicznych i ekonomicznych. Wymiar indywidualno-społeczny problematyki przemocy domaga się ponadto analiz psychologiczno-pedagogicznych, wskazujących na mechanizmy rozwojowe i socjalizacyjne, których konsekwencją mogą być akty przemocy. Z tego względu wszelkie studia dotyczące wybranego obszaru cech różnicujących ludzi (płeć, wiek, rasa czy sprawność), stanowiących najczęściej powód wykluczenia danej grupy i zachowań przemocowych, są studiami interdyscyplinarnymi.

Przemoc wobec osób niepełnosprawnych wymaga studiów interdyscyplinarnych nie tylko dlatego, że wpisuje się w schemat wypracowanych już modeli badań nad płcią, dzieciństwem, rasą czy seksualnością, ale także dlatego, że w najbardziej demokratyczny lub raczej naturalny sposób łączy się z ludzkim bytem niezależnie od płci, rasy, wieku, orientacji seksualnej czy wyznawanej (lub nie) religii.

\section{Rzeczywistość przemocy}

Dane dotyczą przemocy wobec osób niepełnosprawnych nie są tak powszechnie znane i nagłaśniane jak informacje dotyczące przemocy domowej, której ofiarami są niemal bezwyjątkowo kobiety i dzieci, a sprawcami mężczyźni, najczęściej mężowie i ojcowie ${ }^{1}$. Kwestia ratyfikacji przez polski sejm Konwencji

${ }^{1}$ Pod koniec listopada 2014 roku w „Gazecie Wyborczej” (numery 272.8303-274.8305) ukazał się cykl reportaży poświęconych przemocy domowej. Kontekstem publikacji były, poruszone również w niniejszym artykule, trudności z ratyfikacją Konwencji Rady Europy o zapo- 
Rady Europy o zapobieganiu i zwalczaniu przemocy wobec kobiet i przemocy domowej uruchomiła w roku 2014 ideologiczny spór na temat nie tylko źródeł przemocy, ale także płci społeczno-kulturowej czy edukacji równościowej. Analiza prawna projektu ustawy o ratyfikacji Konwencji ${ }^{2}$, starająca się zachować bezstronność swojej oceny, wskazała w pierwszej kolejności, iż „nie wyznaczono odpowiednio i nie opisano stanu stosunków społecznych w zakresie problematyki przemocy wobec kobiet w Polsce, które powinno poprzedzać decyzję o przygotowaniu projektu ustawy". Uwagi krytyczne dotyczyły nie tyle sporu o istotę przemocy, jej przyczyn i skutków oraz wpływu na indywidualne ludzkie losy, ile wątpliwości co do wiarygodności danych statystycznych i poprawności metodologicznej przeprowadzonego sondażu.

Dane liczbowe znaleźć można bardzo łatwo i warto je przytaczać, ale dopiero ich zestawienie z pogłębioną analizą źródeł i uwarunkowań przemocy może przyczynić się do skutecznego przeciwdziałania temu zjawisku. Wiadomo, chociażby, że dobra edukacja równościowa w znaczący sposób może przyczynić się do redukcji zachowań przemocowych, ale jej uproszczone kojarzenie jedynie z równością płci sprawia, iż jest ona z gruntu negowana jako seksualizująca dzieci. W konsekwencji brakuje tego typu działań także w odniesieniu do niepełnosprawności i pozostałych czynników definiujących różnice między

bieganiu i zwalczaniu przemocy wobec kobiet i przemocy domowej. Czytelnik tych publikacji otrzymał nie tylko konkretne przykłady przemocy wobec kobiet, dzieci, osób starszych i niepełnosprawnych, ale również dane liczbowe, z których wynika, że w Polsce co roku 800 tys. kobiet pada ofiarą przemocy domowej, blisko 95\% sprawców przemocy to mężczyźni, w 5\% rodzin stosuje się przemoc wobec osób starszych i niepełnosprawnych, 150 kobiet i około 30 dzieci ginie co roku w wyniku tzw. nieporozumień rodzinnych, około 30 tys. kobiet zostaje co roku zgwałconych, policja od początku roku 2014 do listopada założyła 39 tys. Niebieskich Kart, tylko 30\% kobiet doświadczających przemocy ze strony partnerów zgłasza się na policję. W tym samym czasie ukazała się powieść kryminalna Zygmunta Miłoszewskiego (2014) pt. Gniew, stanowiąca kontynuację i zwieńczenie zarazem losów prokuratora Teodora Szackiego, bohatera bestselerowego cyklu powieści. Autor kryminału, którego tematem wiodącym jest przemoc domowa, posłużył się w swojej fikcyjnej opowieści, informacjami publicystycznymi jako konsekwentnie stosowanymi wstępami kolejnych rozdziałów. W pierwszym z nich czytamy pod datą poniedziałek, 25 listopada 2013, m.in.: „,...] Międzynarodowy Dzień Eliminacji Przemocy wobec Kobiet. Statystyki mówią, że 60 proc. Polaków zna co najmniej jedną rodzinę, gdzie kobieta jest ofiarą przemocy, a 45 proc. żyje lub żyło w rodzinie, w której doszło do przemocy. 19 proc. jest zdania, że nie istnieje coś takiego jak gwałt w małżeństwie, a 11 proc., że uderzenie żony lub partnerki to nie przemoc [...]" (s. 15).

${ }^{2}$ Korzystałem z analizy wykonanej przez Instytut na rzecz Kultury Prawnej Ordo Iuris, zamieszczonej na stronie internetowej Instytutu: http://www.ordoiuris.pl/analiza-projektu-ustawy-oratyfikacji-konwencji-rady-europy-o-zapobieganiu-i-przeciwdzialaniu-przemocy-wobec-kobieti-przemocy-domowej-,3451, analiza-prawna.html (dostęp: 25.11.2014). 
ludźmi. Tymczasem zgodnie z danymi Ogólnopolskiego Pogotowia dla Ofiar Przemocy w Rodzinie „Niebieska Linia”, przemoc wobec osób niepełnosprawnych to zjawisko o dużym nasileniu i różnorodności form.

Ponad 30\% Polaków zna takie przypadki w najbliższym otoczeniu. W $31 \%$ było to bicie, $34,3 \%$ - szarpanie i popychanie, $34,4 \%$ - zamykanie, blisko $40 \%$ - zabieranie pieniędzy i rzeczy, 19,7\% - wykorzystywanie seksualne, a 34,4\% - wytykanie i wyśmiewanie. Aż 78,5\% osób, które o tym wiedza, nie robi nic, by pomóc. Tłumaczą, że zaburzyłoby to relację między niepełnosprawnym a jego opiekunem. A to byłoby dla niepełnosprawnego jeszcze gorsze.

(za: http://wyborcza.pl/1,75248,9826890,Rzeczpospolita_niepelnosprawna.htm1\#ixzz1QBuWef00, dostęp: 26.11.2014)

Do podobnych wniosków doszli brytyjscy badacze, Dan Goodley i Katherine Runswick-Cole (2011), którzy zjawisko przemocy wobec osób niepełnosprawnych powiązali z szerszym pojęciem disablizmu, które oznacza dyskryminację człowieka ze względu na obniżoną sprawność psychofizyczną. Autorzy ci odwołują się w swojej interpretacji prezentowanego zjawiska do pracy Slavoja Žižka (2010), zatytułowanej Przemoc. Sześć spojrzeń z ukosa. Jest to zbiór esejów jednego z najbardziej znanych i wpływowych współczesnych filozofów, wiązanego z myślą lewicową, w których stara się przekonać czytelników do swojej diagnozy przyczyn i uwarunkowań przemocy we współczesnym świecie. $Z$ punktu widzenia podjętych przeze mnie rozważań, a więc przemocy wobec osób niepełnosprawnych, stanowiącej zarazem jeden z najważniejszych obszarów globalnych i interdyscyplinarnych studiów nad niepełnosprawnością (Goodley, 2011, s. 3-5), najbardziej inspirujące wydają się analizy Žižka, dotyczące generowania przez systemy wolnorynkowe (neoliberalne) całych grup społecznych zależnych od pomocy społecznej. Istota marginalizacji i wykluczenia ma swoje źródło w nadmiernej konsumpcji, pracy i zarabianiu, których efektem jest $\mathrm{z}$ jednej strony wykluczenie grup niemogących sprostać presji ekonomicznej, z drugiej natomiast rozrost form wsparcia, której beneficjentami są osoby wcześniej świadomie usunięte z głównego nurtu życia społecznego. Pozory dobroczynności są $\mathrm{w}$ istocie utrwaleniem postaw dyskryminujących wybrane grupy społeczne, prowadząc do znanych już z prac socjologicznych (Bourdieu, Passeron, 1990; Bourdieu, Wacquant, 2001) form przemocy symbolicznej (obecnej głównie w języku) i systemowej (stanowiącej wyraz przekonania o sprawnie funkcjonującym państwie). Dochodzi w tym przypadku do swoistego paradoksu - wolnościowe idee społeczne, kojarzone z klasycznymi 
koncepcjami lewicowymi i liberalnymi, mogą zupełnie nieświadomie prowadzić do niebezpiecznej zależności między nadmiarem bogactwa, nadmiarem wykluczenia i nadmiarem pomagania (Žižek, 2010, s. 35-40).

Interdyscyplinarność studiów nad niepełnosprawnością ma swoje uzasadnienie w sposobie ujmowania zjawiska przemocy. Otóż nie jest możliwe ustalenie istoty zachowań przemocowych bez wyraźnego wskazania historycznych, psychologicznych, socjologicznych, edukacyjnych czy ekonomicznych aspektów kształtowania się postaw dopuszczających ingerencję w wolność osobista oraz niezależność fizyczną i psychiczną człowieka. Najistotniejsze jest jednak wskazanie, że przemoc jest bardzo głęboko zakorzeniona w kulturze i tradycji, które bardzo często utrwalane są również w systemach politycznych, przyjmujących określone rozwiązania $\mathrm{w}$ odniesieniu do przemocy na poziomie prawno-administracyjnym. $Z$ tego powodu przemoc symboliczno-systemowa, jako akceptowana ze względu na utrwalone w danej kulturze, religii czy systemie politycznym schematy relacji społecznych, traktowana jest w studiach nad niepełnosprawnością jako wyzwanie, które w równej mierze, choć w zupełnie innych kontekstach, dotyczy krajów najbogatszych, rozwijających się i tych najbiedniejszych (Goodley, 2011; Goodley, Runswick-Cole, 2011).

Osoby niepełnosprawne cierpią z powodów społeczno-ekonomicznych. W krajach bogatych ekspansja wolnego rynku oraz rozrastanie się usług w zakresie pomocy społecznej i edukacji, którym towarzyszą hasła ,intelektualnego dopasowania się” i „sprostania wymogom pracy”, prowadzą w konsekwencji do wykluczenia osób niepełnosprawnych z rynku pracy. Uszkodzone płody są codziennie usuwane w wyniku postępu w badań medycznych i technologii reprodukcyjnych. Osoby niepełnosprawne są ignorowane, obdarzane litością, traktowane protekcjonalnie, przedmiotowo i fetyszyzująco. Ich kłopotliwa obecność rodzi pytania o „prawo do śmierci” i „wspomagane samobójstwo”. Choć uszkodzone ciało lub umysł od zawsze były częścią codzienności, to poniżający stosunek społeczeństwa wobec osób niepełnosprawnych, który można określić jako upośledzanie (disablement) lub disablizm (disablism), jest historycznie i kulturowo względny. Celem studiów nad niepełnosprawnością jest wyjaśnienie i zrozumienie tej względności (Goodley, 2011, s. 2).

\section{Podsumowanie}

Podjęta w niniejszym artykule problematyka należy do obszarów nadal oczekujących na swoje badawcze zaistnienie. Myślę, że nauki o wychowaniu, ze szczególną w tym przypadku rolą pedagogiki specjalnej, mogą stanowić bardzo 
dobrą platformę integrowania ustaleń różnych dyscyplin naukowych, starających się nie tylko zrozumieć trwałość i wszechobecność zjawiska przemocy, ale także promujących zmianę społeczną jako warunek niezbędny w programach przeciwdziałania przemocy. Zmianę tę należy traktować zarówno jako wyraz indywidualnego rozwoju, w tym nabywania odpowiednich postaw, jak i jako rzeczywisty wymiar humanizacji, a nie tylko humanitaryzacji (w znaczeniu nadmiernych form pomocowych) relacji międzyludzkich. Póki co otrzymujemy dość liczne przykłady analiz publicystycznych, często zbyt jednostronnych i uproszczonych w swoich ustaleniach, ale stanowiących jednocześnie prawdziwe wyzwanie intelektualne i badawcze dla pedagogów specjalnych zorientowanych humanistycznie w swoim podejściu metodologicznym do rzeczywistości wychowawczej. Przykład, którego celem jest zarówno zilustrowanie publicystycznej narracji na temat przemocy wobec osób niepełnosprawnych, jak i otwarte, niedokończone podsumowanie analiz podjętych w niniejszym tekście, pochodzi z tygodnika „Polityka” (Turlej, 2014). Fragment artykułu poświęconego seksualności osób niepełnosprawnych jest moim zdaniem dobrym przykładem ścierania się rzeczywistości utrwalającej model wykluczenia, ignorowania i normatywizowania odmienności oraz tej, która wiąże się ze zmianą - trudnym procesem dorastania. W przypadku przemocy nadal jesteśmy jeszcze na początku drogi ku krytycznej dojrzałości.

Magda, która na jednym z forów prowadzi grupę dyskusyjną dla kobiet z niepełnosprawnością, przyznaje, że w pętaniu seksualności, również tej objętej podwójnym tabu, bo homoseksualnej, przodują internaty dla niewidomych prowadzone przez siostry zakonne. Do niedawna oddzielające chłopców od dziewczyn, coraz częściej decydują się na koedukację, ale starannie pilnują wyznaczonych granic, np. rozdziału na płcie podczas posiłków czy odrabiania lekcji. Kiedy siostry zauważą nastolatków, którzy ich zdaniem żywią do siebie grzeszne uczucia, jednego z nich wysyłają do innego ośrodka. Drugiemu zalecają spowiedź albo post. Czasem też polecają, akurat dostępne w brajlu, żywoty świętych.

Waldek, niedowidzący gej, przyłapany na pocałunku z kolega, po lekturze historii jednego z błogosławionych pustelników zaczął się biczować, spał na krzyżu, kiedy pojawiały się myśli o masturbacji, ostrym drapakiem do garnków pocierał nadgarstki (Turlej, 2014, s. 35). 


\section{Bibliografia}

Boggs C. (1996), Social movement and political power, Temple University Press, Philadelphia.

Bourdieu P., Passeron J. C. (1990), Reprodukcja. Elementy systemu nauczania, przeł. E. Neyman, PWN, Warszawa.

Bourdieu P., Wacquant L. J. D. (2001), Zaproszenie do socjologii refleksyjnej, przeł. A. Sawisz, Oficyna Naukowa, Warszawa.

Czerepaniak-Walczak M. (2006), Pedagogika emancypacyjna. Rozwój świadomości krytycznej człowieka, Gdańskie Wydawnictwo Psychologiczne, Gdańsk.

Czerepaniak-Walczak M. (2005), Przesłanki integracji społecznej i kulturowej-pułapki i izonomii, [w:] T. Żółkowska (red.), Pedagogika specjalna-aktualne osiagnięcia $i$ wyzwania, Oficyna IN PLUS, Szczecin.

Goodley D. (2011), Disability Studies: An Interdisciplinary Introduction, Sage Publications Ltd., London.

Goodley D., Runswick-Cole K. (2011), The violence of disablism, "Sociology of Health and Illness", 33 (4), 602-617.

Krause A. (2010), Wspótczesne paradygmaty pedagogiki specjalnej, Wydawnictwo Impuls, Kraków.

Miłoszewski Z. (2014), Gniew, WAB Warszawa.

Preece J. J. (2007), Prawa mniejszości, przeł. M. Stolarska, Wydawnictwo Sic!, Warszawa.

Turej E. (2014), Seksualni nienormalni, „Polityka” 47 (2985), s. 34-36.

Žižek S. (2010), Przemoc. Sześć spojrzeń z ukosa, przeł. A. Górny, Wydawnictwo Muza, Warszawa. 